\title{
Media Rubik Pada Pembelajaran IPA Pada Penerapan Model Think Pair Share
}

\author{
Lolita Dwi Resmiana1 ${ }^{*}$, Joko Siswanto², Ahmad Nashir Tsalatsa ${ }^{3}$ \\ ${ }^{123}$ Fakultas Ilmu Pendidikan Universitas PGRI Semarang
}

\begin{abstract}
Abstrak
Penelitian ini bertujuan untuk mengetahui seberapa besar pengaruh model pembelajaran TPS berbantu media rubik terhadap hasil belajar IPA Siswa Kelas IV SD Negeri 03 Bulakan Kabupaten Pemalang. Jenis penelitian ini adalah penelitian kuantitatif dalam bentuk Pre-Experimental Design dengan desain One Gruop Pretest Posttest Design. Hasil penelitian menunjukkan adanya peningkatan hasil belajar siswa yang dapat dilihat berdasarkan hasil pre-test dan post-test. Rata-rata nilai pretest yang diperoleh dengan nilai tertinggi 92 dan nilai terendah 44. Sedangkan nilai rata-rata post-test diperoleh dengan nilai tertinggi 100 dan nilai terendah 60 . Hal tersebut telah dibuktikan dalam pengujian hipotesis, yang menyatakan bahwa nilai thitung $\geq$ t-tabel $(17,17>1,980)$ maka H0 ditolak dan Ha diterima. Sehingga dapat disimpulkan bahwa terdapat keefektifan model pembelajaran TPS berbantu media Rubik terhadap hasil belajar IPA Siswa Kelas IV SD Negeri 03 Bulakan Kabupaten Pemalang. Berdasarkan hasil penelitian ini saran yang dapat disampaikan adalah supaya model pembelajaran TPS dan media Rubik dapat digunakan sebagai salah satu alternative guru dalam mengajar.
\end{abstract}

\section{PENDAHULUAN}

Latar belakang yang mendorong penelitian ini adalah rendahnya hasil belajar IPA siswa kelas IV SD Negeri 03 Bulakan Kabupaten Pemalang. Hal ini disebabkan kurangnya pemahaman siswa pada mata pelajaran IPA khususnya materi sumber daya alam. Permasalahan pada penelitian ini bagaimana pengaruh model pembelajaran Think Pair Share (TPS) berbantu media Rubik terhadap hasil belajar IPA Siswa Kelas IV SD Negeri 03 Bulakan Kabupaten Pemalang. Tujuan dari penelitian ini adalah untuk mengetahui pengaruh model pembelajaran TPS berbantu media rubik terhadap hasil belajar IPA Siswa Kelas IV SD Negeri 03 Bulakan Kabupaten Pemalang. Rencana pemecahan masalah yang dihadapi yaitu menggunakan model pembelajaran Think pair Share yang berbantu media rubik agar siswa tertarik dalam pembelajaran di dalam kelas dan siswa tidak mudah bosan untuk menerima pembelajaran.Berdasarkan penelitian jurnal skripsi Program Studi Pendidikan Guru Sekolah Dasar, Fakultas Ilmu Pendidikan Universitas PGRI Semarang dengan berjudul Penelitian Skripsi yang berjudul "Keefektifan Model Pembelajaran Think pair Share berbantu media Audio Visual terhadap hasil belajar IPA Kelas V SD Negeri Bandarjo 03 Ungaran" (Widjayanti, 2017). Dalam hasil penelitiannya dapat disimpulkan bahwa terjadi peningkatan terbukti dalam perhitungan uji-t diperoleh harga thitung = 9,403804298 dan diperoleh ttabel = 1,68709. Karena thitung > ttabel maka dapat disimpulakn H0 ditolak dan Ha diterima, artinya rata-rata nilai tes siswa dengan model pembelajaran Think pair Share berbantu media Audio Visual lebih dari sama dengan KKM yaitu 75. mengelola kelas untuk mengatur jalannya diskusi.

Berdasarkan fakta dilapangan, kondisi yang dilihat sangat berbeda, dimana di SD Negeri 03 Bulakan khususnya kelas IV pembelajaran masih menggunakan pembelajaran konvensional yang lebih menekankan pada metode ceramah. Proses pembelajaran masih berpusat oleh guru, siswa kurang aktif dan malas mengikuti pembelajaran dan hasil belajar IPA yang rendah pada siswa kelas IV yang masih dibawah kriteria ketuntasan minimal (KKM) yang ditetapkan sekolah yaitu 70, Salah satu penyebab

* Corresponding author.

E-mail Addresses: - lolitadwiresmiana@gmail.com (Lolita Dwi Resmiana) 
rendahnya hasil belajar diakibatkan rendahnya pemahaman mata pelajaran IPA kelas IV khususnya materi sumber daya alam.

Masalah-masalah dalam beberapa faktor dalam proses pembelajaran, yaitu : 1) kurangnya variasi dan inovasi pada model pembelajaran; 2) keterbatasan dalam menggunakan media yang menarik; 3) siswa kurang antusias dalam mengikuti pembelajaran; 4) siswa mudah bosan ketika mengikuti kegiatan belajar; 5) siswa sulit berinteraksi dan bekerjasama dalam kelompok. Berdasarkan faktor-faktor tersebut maka dapat disimpulkan bahwa model dan media pembelajaran sangat berpengaruh dalam setiap kegiatan belajar mengajar. Model pembelajaran yang variatif dapat membuat pembelajaran lebih bermakna bagi para siswa dan meningkatkan minat belajarnya dibandingkan dengan menggunakan model atau metode yang konvensional. Pembelajaran juga akan lebih menarik perhatian siswa ketika guru menggunakan media pembelajaran yang lebih menarik sesuai dengan materi pembelajaran yang diajarkan.

Guru perlu menggunakan model pembelajaran yang variatif dan inovatif. Solusi alternatif untuk memperbaiki masalah tersebut yaitu peneliti menerapkan model pembelajaran yang dapat digunakan yaitu model pembelajaran Think Pair Share (TPS) dalam meningkatkan hasil belajar IPA siswa kelas IV SD Negeri 03 Bulakan Kabupaten Pemalang. Dengan menggunakan model pembelajaran TPS dapat memberikan pengaruh pola interaksi bagi siswa dan kesempatan bagi siswa untuk ikut berperan aktif dalam proses pembelajaran yang berlangsung, siswa menjadi aktif selama proses pembelajaran, sehingga dapat diketahui sejauh mana pemahaman siswa tentang materi yang telah disampaikan oleh guru.

Model pembelajaran TPS ini yaitu siswa tidak belajar sendiri namun siswa dapat belajar dengan teman sebangku dalam kelompoknya melalui kegiatan berdiskusi yang dikerjakan secara bersama atau berpasangan untuk dapat menyelesaikan pekerjaan yang diberikan oleh guru. TPS adalah suatu model pembelajaran kooperatif yang memberi siswa waktu untuk berpikir dan merespons serta saling bantu satu sama lain. Model ini memperkenalkan ide "waktu berpikir atau waktu tunggu" yang menjadi faktor kuat dalam meningkatkan kemampuan siswa dalam merespons pertanyaan. Pembelajaran kooperatif model TPS ini relatif sederhana karena tidak menyita waktu yang lama untuk mengatur tempat duduk ataupun mengelompokkan siswa. Pembelajaran ini melatih siswa untuk berani berpendapat dan menghargai pendapat teman (Sa'dijah, 2006: 12) dalam (Shoimin, 2017: 208).

Pembelajaran kooperatif Think Pair Share (TPS) merupakan model pembelajaran kelompok dimana siswa diberi waktu lebih banyak memikirkan jawabannya dan saling membantu satu sama lain (Jannah, 2013). Model pembelajaran TPS ini merupakan suatu cara efektif untuk membuat variasi dan inovasi dalam diskusi di kelas, dengan menggunakan model pembelajaran ini siswa akan menjadi lebih paham karena pada model ini meliputi tiga tahap yaitu : 1) kegiatan berpikir (Think); 2) kegiatan berpasangan (Pair); 3) kegiatan berbagi (Share), sehingga model ini dapat membimbing siswa untuk memiliki rasa tanggung jawab individu dan tanggung jawab dalam kelompok. Hasil dari Model pembelajaran TPS ini yaitu diharapkan akan meningkatkan keaktifan belajar siswa, siswa mampu memecahkan soal permasalahan yang diberikan oleh guru, mampu berdiskusi dan berinteraksi dengan siswa yang lain, berani mengemukakan pendapatnya dan berani untuk bertanya serta membuat pembelajaran menjadi bermakna dan menghasilkan pemahaman yang kuat terhadap para siswa. Tujuan dari pembelajaran kooperatif tipe Think Pair Share (TPS) yaitu untuk meningkatkan penguasaan akademik, mengajarkan keterampilan social dan membantu siswa untuk dapat berpikir kritis, serta meningkatkan pemahaman siswa dalam memahami konsep-konsep pembelajaran (Winantara, 2017)

Disamping mampu menggunakan berbagai model pembelajaran yang variatif guru juga dituntut untuk dapat mengembangkan keterampilan membuat media pembelajaran. Untuk itu guru harus memiliki pengetahuan dan pemahaman yang cukup tentang media pembelajaran yang meliputi (Hamalik, 1994) dalam (Arsyad, 2014: 6): a) media sebagai alat komunikasi guna lebih mengefektifkan proses belajar mengajar; b) fungsi media dalam rangka mencapai tujuan pendidikan; c) seluk-beluk proses belajar; d) hubungan antara metode mengajar dan media pendidikan; e) nilai atau manfaat media pendidikan dalam pengajaran; f) pemilihan dan penggunaan media pendidikan; g) berbagai jenis alat dan teknik media pendidikan; h) media pendidikan dalam setiap mata pelajaran; i) usaha inovasi dalam media pembelajaran.

\section{METODE PENELITIAN}

Metode penelitian yang digunakan dalam penelitian ini adalah menggunakan metode penelitian kuantitatif. Metode kuantitatif dapat diartikan sebagai metode penelitian yang berlandaskan pada filsafat positivisme, digunakan untuk meneliti pada populasi atau sampel tertentu, teknik pengambilan sampel pada umumnya dilakukan secara random, pengumpulan data menggunakan instrumen penelitian, analisis data bersifat kuantitatif / statistik dengan tujuan untuk menguji hipotesis yang telah ditetapkan 
(Sugiyono, 2017: 14). Metode penelitian yang akan digunakan adalah metode penelitian eksperimen. Metode eksperimen adalah metode penelitian kuantitatif yang digunakan untuk mengetahui pengaruh variabel independen (treatmen/perlakuan) terhadap variabel dependen (hasil) dalam kondisi yang terkendali (Sugiyono, 2018: 111). Teknik pengumpulan data yaitu menggunakan tes, wawancara, dan dokumentasi.

Berdasarkan permasalahan yang ada, penelitian ini menggunakan dua macam variabel yaitu: 1. Variabel bebas (X) : Menurut Sugiyono (2016: 61) variabel bebas merupakan variabel yang mempengaruhi atau yang menjadi sebab perubahannya atau timbulnya variabel terikat. Variabel bebas dalam penelitian ini adalah Model Pembelajaran TPS berbantu media rubik bergambar. 2. Variabel terikat (Y) Menurut Sugiyono (2016: 61) variabel terikat merupakan variabel yang dipengaruhi atau yang menjadi akibat, karena adanya variabel bebas. Variabel terikat dalam penelitian ini adalah hasil belajar IPA siswa kelas IV SD Negeri 03 Bulakan Kabupaten Pemalang. Teknik analisis yang digunakan yaitu menggunakan Uji Normalitas, Uji Homogenitas, Uji Hipotesis, dan Uji n-Gain.

\section{ANALISIS DAN PEMBAHASAN}

Uji normalitas nilai Pre-test dan Post-test digunakan untuk mengetahui apakah nilai Pre-test dan Post-test berdistribusi normal atau tidak. Kriteria dalam uji normalitas dengan menggunakan uji liliefors adalah apabila L0 < Ltabel, maka sampel berasal dari populasi berdistribusi normal dan apabila L0 > Ltabel maka sampel berasal dari populasi tidak berdistribusi normal. Data perhitungan hasil normalitas dari data Pre-test dan Post-test disajikan dalam Tabel 1.

Tabel 1. Uji Normalitas Pre-test dan Post-test

\begin{tabular}{ccccc}
\hline Nilai & Rerata & L0 & Ltabel & Keterangan \\
\hline Pre-test & 65 & 0,1443 & 0,147 & Berdistribusi Normal \\
Post-test & 82 & 0,0905 & 0,147 & Berdistribusi Normal \\
\hline
\end{tabular}

Berdasarkan tabel 1 diatas, hasil perhitungan data dari nilai Pre-test diperoleh L0 = 0,1443 dengan $\mathrm{n}=36$ dan taraf nyata 5\% dari daftar nilai kritis didapat Ltabel $=0,147$. Karena L0 < Ltabel yaitu 0,1443< 0,147 pada aspek kognitif. Maka H0 diterima sehingga sampel berasal dari populasi yang berdistibusi normal. Hasil perhitungan data dari nilai Post-test diperoleh L0 $=0,0905$ dengan $\mathrm{n}=36$ dan taraf nyata $5 \%$ dari daftar nilai kritis didapat Ltabel =0,147. Karena L0 < Ltabel yaitu 0,0905 $<0,147$ pada aspek kognitif. Maka H0 diterima sehingga sampel berasal dari populasi yang berdistibusi normal.

Tipe soal yang digunakan pada pretest dan posttest sesuai dengan kisi-kisi soal yang telah dibuat. Soal pretest dan posttest sama akan tetapi pada soal posttest dibuat berbeda pada urutan penomorannya. Berikut data nilai pretest dan posttest subtema 1 jenis-jenis pekerjaan kelas IV SD Negeri 03 Bulakann yang disajikan dalam bentuk Diagram :

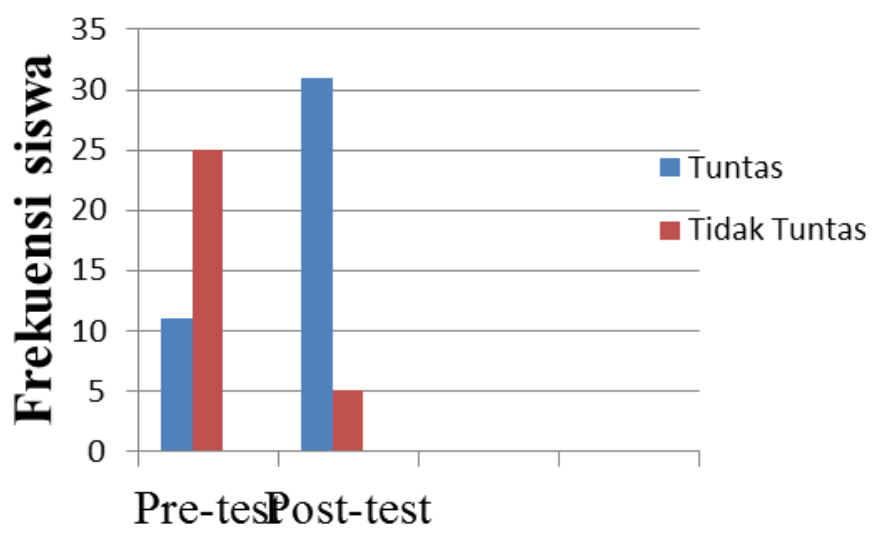

Gambar 1. Diagram Batang Hasil Belajar Pre-test dan Post-test

Berdasarkan Diagram 1 hasil pre-test kelas IV di atas diketahui bahwa nilai rata-rata kelas IV yaitu 65 Sedangkan siswa yang mencapai nilai tuntas ada 11 dan siswa yang belum tuntas ada 25 siswa. Hasil 
Post-test kelas IV di atas diketahui bahwa nilai rata-rata kelas IV yaitu 82 Sedangkan siswa yang mencapai nilai tuntas ada 31 dan siswa yang belum tuntas ada 5 siswa.

Perbandingan antara nilai pre-test yang dilakukan sebelum pembelajaran dengan nilai posttest yang diperoleh pada akhir pembelajaran dan setelah diberi perlakuan dengan model pembelajaran TPS mengalami kenaikan. Seperti yang terlihat di tabel 4.2, Nilai post-test tertinggi yaitu 100, dan terendah yaitu 60 , dan hanya terdapat 5 siswa yang tidak mencapai Kriteria Ketuntasan Minimum (KKM). Hal tersebut menunjukkan bahwa terdapat peningkatan dari nilai pre-test yang sebelum diberikan perlakuan dengan nilai post-test yang sudah diberikan perlakuan dengan model pembelajaran TPS berbantu media rubik. Kenaikan hasil belajar siswa pada pembelajaran subtema 1 jenis-jenis pekerjaan ditandai dengan nilai rata-rata post-test lebih besar dari pre-test yaitu 82.

Jadi dapat disimpulkan bahwa perlakuan yang diberikan yaitu pembelajaran menggunakan model pembelajaran TPS berbantu media rubik mampu meningkatkan hasil belajar psikomotor kelas IV SD Negeri 03 Bulakan.

Uji normalitas nilai Pre-test dan Post-test digunakan untuk mengetahui apakah nilai Pre-test dan Post-test berdistribusi normal atau tidak. Kriteria dalam uji normalitas dengan menggunakan uji liliefors adalah apabila L0 < Ltabel, maka sampel berasal dari populasi berdistribusi normal dan apabila L0 > Ltabel maka sampel berasal dari populasi tidak berdistribusi normal. Data perhitungan hasil normalitas dari data Pre-test dan Post-test disajikan dalam Tabel 2.

Uji homogenitas digunakan untuk mengetahui apakah kedua test mempunyai varian homogen atau tidak. Dalam penelitian ini digunakan dua buah sampel yaitu Pre-test dan Post-test. Uji homogenitas dihitung dengan menggunakan rumus uji F.

Tabel 2. Hasil Uji Homogenitas Nilai Pre-test dan Post-test

\begin{tabular}{ccccc}
\hline Nilai & Rata-rata & f-hitung & f-tabel & Keterangan \\
\hline Pre-test & 65 & 1,56 & 1,76 & H0 Diterima artinya varians \\
Post-test & 82 & & & homogen \\
\hline
\end{tabular}

Tabel 2 menunjukkan bahwa diperoleh Fhitung sebesar 1,56 dengan $\mathrm{n} 1=36$ dan $\mathrm{n} 2=36$. Diperoleh ftabel sebesar 1,76. Jadi fhitung < ftabel maka H0 diterima. Berdasarkan perhitungan data disimpulkan bahwa mempunyai varians yang homogen.

Uji hipotesis pada penelitian ini, peneliti menggunakan uji t yang dilakukan untuk membandingkan hasil data pre-test dan post-test serta menentukan ada atau tidaknya perbedaan sebagai akibat dari perlakuan X yaitu pembelajaran dengan menggunakan model pembelajaran TPS berbantu media rubik dianalisis dengan uji t. Hipotesis yang diajukan dalam penelitian ini adalah terdapat pengaruh pembelajaran sumber daya alam menggunkan model pembelajaran TPS berbantu media rubik pada subtema jenis-jenis pekerjaan kelas IV SD Negeri 03 Bulakan.

H0 : Model pembelajaran Think Pair Share (TPS) berbantu media rubik tidak berpengaruh secara signifikan terhadap hasil belajar IPA materi sumber daya alam siswa Kelas IV SD Negeri 03 Bulakan Kabupaten Pemalang.

Ha : Model pembelajaran Think Pair Share (TPS) berbantu media rubik berpengaruh secara signifikan terhadap hasil belajar IPA materi sumber daya alam siswa Kelas IV SD Negeri 03 Bulakan Kabupaten Pemalang.

Setelah dilakukan analisis maka disajikan pada Tabel sebagai berikut :

Tabel 3. Daftar hasil Uji-t Nilai Pre-test dan Post-test

\begin{tabular}{lllll}
\hline Nilai & Rata-rata & t-hitung & t-tabel & Keterangan \\
\hline Pre-test & 65 & 17,17 & 1,980 & $\begin{array}{l}\text { H0 Ditolak sehingga terdapat } \\
\text { pengaruh }\end{array}$ \\
Post-test & 82 & & & \\
\hline
\end{tabular}

Kriteria pengujian Ha diterima apabila thitung $\geq$ ttabel dengan $\mathrm{db}=\mathrm{n}-1$ dengan taraf signifikasi 5\% dan untuk harga thitung $\geq$ ttabel maka HO Ditolak. Setelah dilakukan analisis data nilai hasil belajar pada aspek kognitif diperoleh rata-rata untuk pretest sebesar 65 dan posttest sebesar 82 dengan $\mathrm{N}=36$ jadi $\mathrm{db}=$ $36+36-1=71$ yang diperoleh thitung $=17,17$ dengan taraf signifikan $5 \%$ didapat nilai ttabel $=1,980$. Karena thitung $=17,17 \geq$ ttabel $=1,980$ maka $\mathrm{HO}$ ditolak sehingga terdapat pengaruh pembelajaran subtema jenis-jenis pekerjaan materi sumber daya alam menggunakan model pembelajaran TPS berbantu media rubik di SD Negeri 03 Bulakan. 
Gain merupakan selisih antara nilai pre-test dan post-test, gain menunjukkan selisih skor atau nilai yang di peroleh dari hasil pre-test dan post-test. n-Gain merupakan indikator yang baik untuk menunjukkan tingkat keefektifan pembelajaran yang dilakukan dilihat dari peningkatan kemampuan siswa.

Tabel 4. Distribusi N-Gain

\begin{tabular}{llll}
\hline & & N-Gain & \\
Nilai & Rata-rata & Nilai & Kriteria \\
\hline Pre-test & 65 & & Tinggi \\
Post-test & 82 & 0,89 & \\
\hline
\end{tabular}

Model pembelajaran TPS berbantu media rubik memperoleh n-Gain sebesar 0,89 yang artinya nilai pre-test dan post-test dikategorikan tinggi karena $\mathrm{g}>0,70$.

Penelitian ini dilaksanakan pada semester gasal, pada tanggal 28 Mei sampai 15 November 2018 di SD Negeri 03 Bulakan Kabupaten Pemalang, penelitian ini merupakan penelitian eksperimen dengan desain yang digunakan dalam penelitian ini adalah Pre-Experimental Design dengan bentuk one-group pretest-posttest design, dalam penelitian ini desai menggunakan satu kelas. Sebelum melaksanakan penelitian, peneliti melakukan studi pendahuluan pada tanggal 10 Juli 2018 untuk mengetahui permasalahan yang ada di kelas dan diperoleh informasi bahwa pembelajaran belum menggunakan model pembelajaran yang menarik sehingga siswa bosan dan tidak memperhatikan pembelajaran, serta kurangnya media pembelajaran yang digunakan. Pembelajaran yang dilakukan oleh guru didominasi pada oleh penggunaan ceramah, guru hanya sebatas menyampaikan materi dan siswa hanya menerima materi yang disampaikan oleh guru. Akibat yang muncul karena permasalahan tersebut yaitu berdampak pada hasil belajar kognitif siswa kelas IV pada pelajaran IPA masih tergolong rendah. Hal ini ditunjukan oleh nilai rata-rata masih kurang dari Kriteria Ketuntasan Minimun (KKM). KKM yang ditetapkan sekolah yaitu 70 .

Model pembelajaran TPS memiliki prosedur secara eksplisit memberi siswa waktu untuk berpikir, menjawab, saling membantu satu sama lain. Dengan demikian, diharapkan siswa mampu bekerja sama, saling membutuhkan, dan saling bergantung pada kelompok kecil secara kooperatif (Shoimin, 2017: 209). Menurut Huda (2013: 206), model pembelajaran TPS ini memiliki manfaat antara lain adalah : 1) memungkinkan siswa untuk bekerja sendiri dan bekerja sama dengan orang lain; 2) mengoptimalkan partisipasi siswa; sdan 3) memberi kesempatan kepada siswa untuk menunjukan partisipasi mereka kepada orang lain. Skill-skill yang umumnya dibutuhkan dalam strategi ini adalah sharing informasi, bertanya, meringkas gagasan orang lain dan paraphrasing.

Pembahasan ini berisi tentang hasil penelitian yang dilaksanakan oleh peneliti pada siswa kelas IV SD Negeri 03 Bulakan. Peneliti menggunkan model pembelajaran TPS dan berbantu media rubik. Berdasarkan hasil rata-rata nilai post-test lebih besar dibandingkan dengan nilai rata-rata pre-test. Hasil nilai rata-rata pre-test yaitu 65 sedangkan nilai rata-rata post-test yaitu 82 . Hal ini karena adanya perlakuan yang berbeda pada pembelajaran. Pembelajaran yang menggunakan model pembelajaran TPS berbantu media rubik lebih berpengaruh karena siswa lebih mudah menerima materi.

Dalam model pembelajaran TPS, siswa lebih aktif dalam mengikuti pembelajaran serta lebih mudah menyerap materi yang disampaikan oleh guru. Sedangkan saat pre-test, siswa hanya diberi perlakuan dengan metode konvensional dan tidak mengunakan model pembelajaran TPS dapat dinyatakan bahwa siswanya kurang aktif, siswa hanya sebagai penerima gagasan dari guru tanpa bisa menggali pengetahuan dan menyelesaikan masalah. Sehingga kemampuan berpikir kritis siswa masih rendah. Tampak jelas selisih nilai yang didapatkan siswa pada nilai pre-tet dan post-test.

Berdasarkan uji statistika yang dilakukan peneliti, model pembelajaran TPS terbukti berpengaruh dalam meningkatkan hasil belajar IPA. Penelitian dilaksanakan pada tanggal 12 sampai 15 November 2018. Penelitian dimulai dengan memberikan pre-test dan diakhiri dengan memberikan post-test dan dapat diketahui rata-rata dari pre-test dan post-test terlihat dalam Diagram 4.1 halaman 57 . Hal ini sependapat dengan penelitian yang telah dilakukan oleh Ningrum (2017) dari Universitas PGRI semarang dalam hasil penelitiannya bahwa pembelajaran yang dilakukan menggunakan model TPS berpengaruh meningkatkan hasil belajar siswa.

Untuk mengetahui sampel memiliki varians homogen maka dilakukan uji homogenitas nilai pre-tet dan post-test, berdasarkan perhitungan data kedua sampel memiliki varias yang sama atau dapat dikatakan varian homogen, dapat dilihat pada Tabel 4.5 halaman 61.

Analsis data dilakukan dengan rumus statistika uji-t. Namun sebelum uji-t dilakukan, terlebih dahulu dilakukan uji normalitas awal dengan menggunakan pre-test. Uji normalitas dilakukan untuk 
mengetahui sampel berdistribusi normal atau tidak normal. Berdasarkan perhitungan yang telah dilakukan diperoleh kesimpulan bahwa nilai pre-tet dan post-test kelas IV SD Negeri 03 Bulakan berdistribusi normal dapat dilihat di Tabel 4.4 halaman 60 .

Berdasarkan uji paired samples t-test yaitu dengan membandingkan hasil belajar pre-tet dan posttest $\mathrm{H}_{0}$ diterima dapat dilihat di Tabel 4.6 halaman 63, sehingga terdapat pengaruh pelajaran IPA materi sumber daya alam menggunakan model pembelajaran TPS berbantu media rubik di SD Negeri 03 Bulakan.

Pada penelitian ini tidak hanya mengukur perbedaan antara hasil belajar siswa yang mendapatkan pembelajaran dengan model pembelajaran TPS. Pada penelitian ini juga mengukur tentang seberapa pengaruh model pembelajaran TPS. Peneliti mengukur dengan uji N-Gain. Uji N-Gain dilaksanakan dengan menghitung selisih nilai pre-test dan post-test. Dari hasil pengujian N-Gain didapatkan nilai sebesar 0,50 yang telah disajikan dalam bentuk Tabel 4.7 halaman 64.

Selain mengukur nilai dari aspek kognitif (pre-test dan post-test), peneliti juga mengukur dari aspek keterampilan. Pada aspek keterampilan terdapat 3 kriteria, dari masing-masing kriteria mempunyai rata-rata kelas. Nilai diambil saat siswa melakukan pre-test dan post-test. Rata-rata tersebut sudah disajikan dalam Tabel 4.3 halaman 59.

Dari pembahasan di atas, dapat disimpulkan bahwa pembelajaran dengan menggunakan model pembelajaran TPS berbantu media rubik lebih baik daripada menggunakan metode konvensional, karena rata-rata nilai tes akhir siswa IV yang diberi pembelajaran dengan menggunkan model pembelajaran TPS berbantu media rubik lebih tinggi dibandingkan dengan rata-rata tes akhir siswa kelas IV sebelum diberi pembelajaran dengan menggunakan model pembelajaran TPS berbantu media rubik. Dengan demikian terdapat pengaruh hasil belajar siswa pada pelajaran IPA materi sumber daya alam dari penggunaan model pembelajaran TPS berbantu media rubik.

\section{KESIMPULAN}

Berdasarkan rumusan masalah, hipotesis, analisis data penelitian, dan pembahasan maka diperoleh kesimpulan bahwa terbukti terdapat pengaruh model pembelajaran TPS berbantu media rubik terhadap hasil belajar siswa pada mata pelajaran IPA materi sumber daya alam kelas IV SD Negeri 03 Bulakan dengan nilai siswa mengalami peningkatan baik dari aspek kognitif dan aspek keterampilan.

Saran yang di ajukan dalam penelitian ini adalah (1) Model pembelajaran TPS berbantu media rubik sangat berpengaruh terhadapat peningkatan hasil belajar kognitif siswa, sehingga dapat digunakan sebagai model pembelajaran alternatif dalam pembelajaran IPA. (2) Pembelajaran dengan menggunakan model pembelajaran TPS ini dapat dikolaborasikan dengan media lainnya sesuai dengan situasi, kondisi sekolah dan sesuai dengan kebutuhan. (3)Pembelajaran dengan menggunakan model pembelajaran TPS berbantu media rubik menjadikan siswa lebih aktif dalam pembelajaran sehingga dapat menumbuhkan pola pikir siswa yang kreatif dan kritis dalam menemukan ide, serta dapat memotivasi siswa untuk semangat belajar.

\section{DAFTAR PUSTAKA}

Arsyad, A. 2014. Media Pembelajaran. Jakarta: Rajawali Pers.

Budiastuti, S.A., Mardiyana, M. and Triyanto, T., 2013. Eksperimentasi Model Pembelajaran Kooperatif Think Pair Share dan Team Assisted Individualization Pada Materi Trigonometri Ditinjau Dari Minat Belajar Matematika Siswa SMK di Kabupaten Ponorogo Tahun Pelajaran 2011/2012. Jurnal Pembelajaran Matematika, 1(4).

Harahap, F. and Sinuraya, J., 2013. Pengaruh Model Pembelajaran Inquiry Training Terhadap Hasil Belajar Siswa Pada Materi Pokok Suhu Dan Pengukuran Kelas VII Semester I MTs N 2 Medan TP 2012/2013. INPAFI (Inovasi Pembelajaran Fisika), 1(1).

Huda, M. 2013 Model-Model Pengajaran dan Pembelajaran. Yogyakarta: Pustaka Pelajar.

Husna, M. and Fatimah, S., 2013. Peningkatan kemampuan pemecahan masalah dan Komunikasi matematis siswa Sekolah Menengah Pertama melalui model pembelajaran kooperatif tipe Thinkpair-share (TPS). Jurnal Peluang, 1(2), pp.81-92. 
Ikhsan, M., 2014. Penggunaan Model Pembelajaran Kooperatif Tipe Think-Pair-Share (TPS) untuk Meningkatkan Kemampuan Komunikasi dan Disposisi Matematis Siswa di SMA Negeri 1 Bireuen. Jurnal Didaktik Matematika, 1(1).

Jalil, M., 2016. Pengembangan Pembelajaran Model Discovery Learning berbantuan tips powerpoint interaktif pada materi interaksi makhluk hidup dengan lingkungan. Refleksi Edukatika: Jurnal Ilmiah Kependidikan, 6(2).

Jannah, R., Saputro, A.N.C. and Yamtinah, S., 2013. Penerapan model pembelajaran Think Pair Share (TPS) disertai buku saku untuk meningkatkan aktivitas dan prestasi belajar kimia pada materi minyak bumi kelas X SMA Negeri Gondangrejo tahun pelajaran 2012/2013. Jurnal Pendidikan Kimia, 2(4), pp.19-23.

Kusuma, F.W. and Aisyah, M.N., 2012. Implementasi Model Pembelajaran Kooperatif Tipe think pair share untuk meningkatkan aktivitas belajar akuntansi siswa kelas XI IPS 1 SMA Negeri 2 Wonosari tahun ajaran 2011/2012. Jurnal Pendidikan Akuntansi Indonesia, 10(2).

Shoimin, A. 2017. 68 Model Pembelajaran Inovatif Dalam Kurikulum 2013. Yogyakarta. Ar-Ruzz Media.

Sugiyono. 2018. Metode Penelitian Kuantitatif. Bandung. Alfabeta.

Surayya, L., Subagia, I.W., Tika, I.N. and Si, M., 2014. Pengaruh model pembelajaran think pair share terhadap hasil belajar IPA ditinjau dari keterampilan berpikir kritis siswa. Jurnal Pendidikan dan Pembelajaran IPA Indonesia, 4(1).

Widjayanti T A. 2017. Keefektifan model pembelajaran Think Pair Share berbantu media audio visual terhadap hasil belajar IPA KELAS V SD Negeri bandarjo 03 ungaran. Skripsi PGSD. Universitas Pgri Semarang

Winantara, I.D. and Jayanta, I.N.L., 2017. Penerapan Model Pembelajaran TPS Untuk Meningkatkan Hasil Belajar IPA Siswa Kelas V SD No 1 Mengwitani. Jurnal Ilmiah Sekolah Dasar, 1(1), pp.9-19. 